одноклассников, жизнь заключается в общении в виртуальном мире, знакомы они только «по никам». И в этой школе решили провести экзамены в устной форме. Для ребят, способных набрать текст быстрее, чем это же произнести вслух, сдача устных экзаменов становится серьезным испытанием. Мы видим, к чему приводит зависимость от телефонов и компьютеров. «Я уже, наверное, полгода ручку вообще в руках не держала» [1]. Авторы показывают нам и отношение ребят к дружбе. «Мы с ним дружим. Даже один раз вместе в кафе ходили, когда у меня День рождения был. Я про них все-все знаю. И аську, и мейл» [1].

По контрасту авторы показывают жизнь ребят в 1980 году. Школьники того времени в свободное от учебы время любят читать книги, часто встречаются во дворе и общаются. Также по-новому смотрят ребята на то, что кажется сейчас естественным, а раньше, оказывается, было предметом мечтаний многих подростков. Это и интернет, и графические редакторы, и продукты питания. Поменявшись местами, герои вначале многое не понимают в другом времени, но постепенно привыкают и начинают искать выход, чтобы вернуться домой. А для этого необходимо проявить свои лучшие качества: умение дружить, прощать, быть смелым в отстаивании своего мнения.

Писатели помогают осмыслить место компьютера и телефона в нашей жизни, предостерегают от опасностей виртуального общения, показывают роль настоящего общения с подлинной дружбой. Повесть учит дружить, никогда не отчаиваться, а самое главное понять, что время всегда хорошее.

Современная подростковая литература поднимает важные вопросы поведения ребят в обществе, показывает пути решения конфликтных ситуаций, учит преодолению трудностей в общении, помогает посмотреть со стороны на себя и свою зависимость от виртуального пространства. В книгах современных писателей мы сталкиваемся с такими жизненными ситуациями и проблемами, которые есть в реальной жизни. Ребята пытаются найти свое место в мире, в новом коллективе, отстаивают правду, борются со злом и несправедливостью.

Писатели дают уроки мудрости и милосердия, а также показывают, как правильно поступать в той или иной ситуации нравственного выбора. Литература дает возможность подросткам применять усвоенные нормы морали и нравственности в своей жизни.

$$
* * *
$$

1. Жвалевский А.В., Пастернак Е.Б. Время всегда хорошее. - М.: Время, 2017. - 240 с.

2. Самарский М.А. Радуга для друга. - М.: Эксмо, 2012. - 256 с.

\title{
Moiseeva A.V. \\ Psycholinguistic factors affecting the process of text perception
}

Bashkir State University

(Russia, Ufa)

doi: 10.18411/trnio-10-2021-136

\section{Abstract}

The article deals with the extra linguistic characteristics of the text from the view point of information perception and interpretation processes. The factors leading to the semantic variability of comprehension as a result of the process of perception are analyzed.

Keywords: perception, sense processing, content, psycholinguistic characteristics, attitudes.

\section{Аннотация}

В статье рассматриваются экстралингвистические параметры с точки зрения процессов восприятия и интерпретации текстовой информации. Анализируются факторы, приводящие к смысловой вариативности понимания как результата процесса восприятия.

Ключевые слова: восприятие, смысловая обработка, содержание, психологические особенности, установки. 
The problems of perception and understanding of a speech message have long been in the focus of psycholinguistics. This is explained by the requirements of the human intellectual activity modeling and formalization, as well as the needs of improving education, putting forward the task of optimizing the processes of texts manipulation.

The analysis of the main ideas of the psycholinguistics of speech perception and speech psychology showed that the text comprehension depends on the linguistic and individual psychological characteristics of the recepient, on complex mental activity during the semantic processing of speech information, which is characterized by creation of an integral image of the text semantic content in the consciousness of the perceiving subject.

The semantic variability of the text in its perception is the result of the correlation of linguistic and psychological categories in the process of text perception and comprehension.

Among the psychological factors, there are: characteristics of the personality, acting as a subject of perception and comprehension; parameters of the text and the reality that is reflected in this text [Moiseeva 2014]; the situation in which the process of perception and understanding takes place [Peshkova 2021].

A person perceives and processes information as an integral system having individual psychophysiological, psychological and social characteristics (differences in mental processes, orientation and characterological properties, social class and ideological affiliation, etc.).

The most important of the mechanisms that act upon the recepient's contact with the text is the attitude of perception. This is readiness, predisposition, depending on the fundamental components of people's consciousness, to react in a certain way proper to its relation to the information offered.

Depending on their content, attitudes predetermine the nature of perception and therefore, at its first steps, they become pre-dispositional factors.

The first stage of the attitudes performance is search operations, during which, in accordance with the principles to live by, values and aspirations of the recipients, the source of the text message is selected and the relation towards it as a whole and towards its individual components (authors, section, etc.) is determined. At this stage, a preliminary assessment of the possible information content of the works that have found themselves in the field of perception arises and in accordance with this, the main subject of perception is determined.

The second stage is perception itself. Being involved in the process of contact with information, attitudes predetermine the selection of information (selectivity of perception), their significance for the recipient, and then the transferenc for storage (selectivity of memorization).

Termination of contact with the text (i.e. completion of reading or viewing) does not mean that its perception is over, since attitudes are also determined by postdispositional actions - the third stage of perception, during which the "aftereffect" of what was previously perceived is detected, information is processed and included into a system of consciousness, in one way or another, that is being restructured under the influence of the recepient.

Attention to the perception of the text depends on its significance for the recipient. What is more, the higher the attention, the more details are noticed in the process of perception (analytical effect), the stronger the impression (fixing effect) and the clearer the perception (reinforcing effect).

The process of perception is also greatly influenced by: the activity status of the individual; his social status associated with the belonging of the subject of perception to a certain social (professional, class, etc.) environment; sociocultural status; psychological personality traits.

1) Activity status. Considering the characteristics of a person as a subject of perception and comprehension, one should indicate, first of all, the nature of the activity carried out by a person and the degree of his/her involvement in this activity. Since the comprehension and understanding of reality is possible only in the context of purposeful activity, it is due to the great variety of explicit and extremely difficult mediated goals pursued by a person. The more complex the goals, the more relationships have to be taken into account, the deeper it is 
required to penetrate into the essence of phenomena and the greater the degree of comprehension is achieved.

2) Social status. First of all, it refers to the process of perception of mass communication texts. The influence of the social characteristics of the individual on the process of information processing is expressed in the fact that the content of any perceived message will be interpreted through the prism of group interests. Thus, both the very existence of the communicative process and the content of the transmitted messages largely depend on the nature of the social system within which the communication is carried out.

It should be noted that the selection and interpretation of signals depends on the expectations of a person, which in turn are acquired in the process of participation in an organized society. That is why, from the point of view of the social approach, despite the seeming individuality of the act of perceiving messages, the consumer of the information is not a single person, but the audience, as a set of people perceiving information, since the feeling of the importance and topicality of a particular text for an individual is a transformed form of awareness about the importance of a given text messages for other people.

3) Sociocultural status. It is generally accepted that the perception and processing of information is carried out by a person on the basis of knowledge, values, norms already in his mind, to the extent of his general and special abilities. In general, the consciousness of a person who perceives and processes the text can be represented as a kind of filter, which allows some information to pass completely, other deforms, and others completely discards. From this point of view, the recipient's consciousness can be viewed as a unity of three sides: a set of household activities since the recipient lives and acts (a kind of world of realities); a set of socio-cultural samples, that is, value concepts (ideological, ethical, aesthetic and other values, etc.); the aggregate of knowledge possessed by the individual and with the help of which he explains everything that happens around him (the world of knowledge). Each of these spheres acts as a special filter for the perception of information and presets a special requirement for the text.

4) Psychological status. The process of text perception is influenced by the individual neurophysiological configuration of the brain structures responsible for information processing. Modern science has found that four areas are responsible for the production and processing of information in the human brain, which are located symmetrically in the right and left hemispheres: the left temple - simple logical constructions, the left forehead - complex logical constructions, the right temple - simple emotional and sensory impressions, the right forehead - complex emotional and sensory impressions.

For one reason or another, different lobes of the cerebral cortex can be developed to varying degrees. As a result, a person will perceive information selectively.

Comprehension is closely related not only to the intellectual, but also to the emotional maturity of a person. And the case is not only that the work of thinking gives a person great emotional pleasure. The case is that the level of emotional involvement of a person in the process of comprehension stimulates this procedure, including such levels of consciousness and subconsciousness that remain forever sealed in a non-emotional person.

Being quite different in their viewpoints, people also differ in the aspect in which they perceive the same objects. It is impossible to see the same object exactly as another person sees it, without taking exactly the same point of view, without taking his/her position. Therefore, not a single recipient is able to absolutely adequately perceive the meanings that were put into the text by its creator [Titlova 2016]. But the creator of the text cannot fully simulate the perception of the exact individual and predict possible distortions of his/her thoughts.

The effectiveness of the text perception and comprehension largely depends on the characteristics of the text itself. Among these features, the closeness of the text content to the 
interest and needs of a person, the quality of the content and the difficulty of the text are of paramount importance.

In other words, it can be assumed that in the process of perceiving a text, a person evaluates it according to three groups of parameters. One group is associated with the instrumental role of this text, the degree of its usefulness, the ability to use it in practice. The second group of parameters is associated with the compliance of the text content with the reality that a person knows. The third group of parameters is associated with skills and professionalism of the creator of this text.

Regarding the proximity of the content of the text to the interest and needs of the recipient, one should first of all point out the fact that between the subject as the unity of his social, psychological and semiotic characteristics and the text acting as an object of perception and comprehension, there are very complex relationships that can be described using the term "distance". The length of this distance between the content of the text and the subject perceiving it is determined by the aforementioned higher activity, social, socio-cultural and psychological parameters of the text and the individual.

$$
* * *
$$

1. Moiseeva A.V. On the connection between the verbal and non-verbal components of the creolized text of a glamorous magazine // Intercultural $\leftrightarrow$ Intracultural communication: theory and practice of teaching and translation. Materials of the III international scientific and methodological conference: ed. Peshkova N.P. - Ufa, 2014.S. 32-36.

2. Peshkova N.P. Time and emotions in the text and in the mind of its addressee // Cognitive studies of language. Tambov, 2021. No. 3 (46). S. 824-827.

3. Titlova A.S. On the features of experimental methods in the study of the processes of perception and understanding of microblogging texts // Actual problems of Russian and comparative philology: theory and practice. Materials of the International Scientific and Practical Conference. - Ufa, 2016.S. 403-407. 